
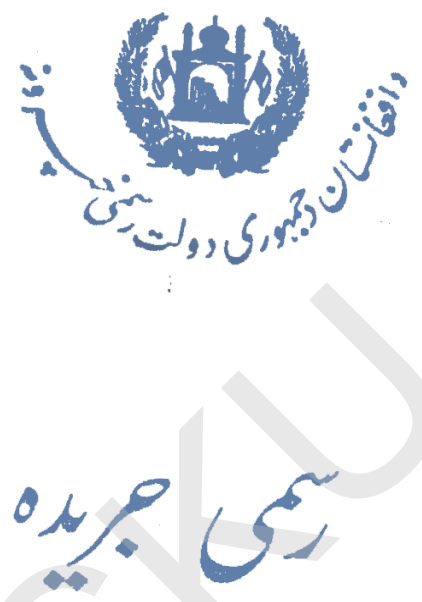

$$
\begin{aligned}
& \text { (YM) } d \text { ars }
\end{aligned}
$$

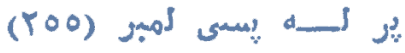




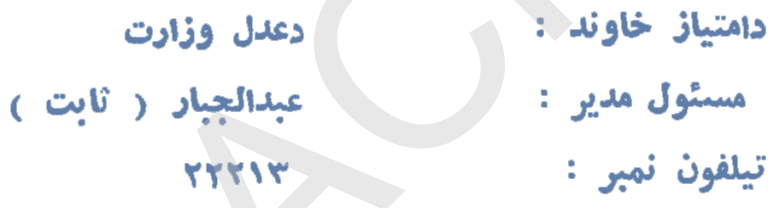

קته : رمسمى جريده، كابل افغا نستان 


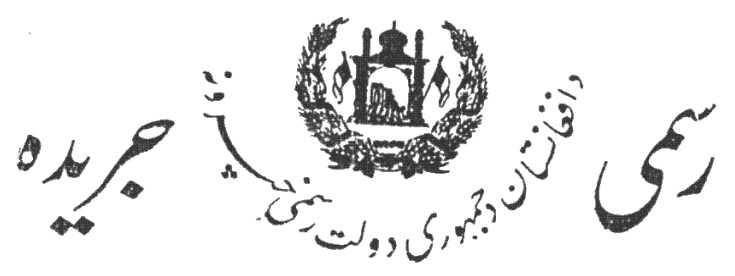

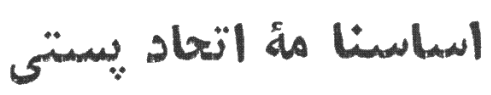

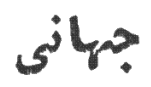

دجهانى بستى دانتحاديى اساسناسم لهاس

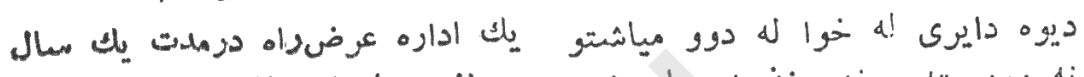

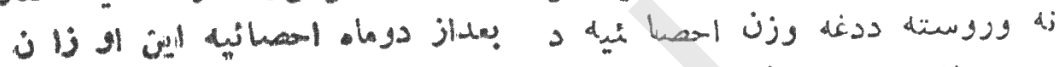

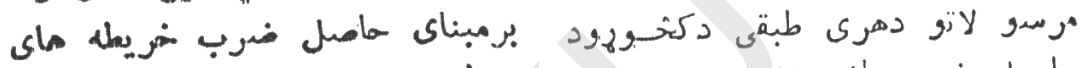

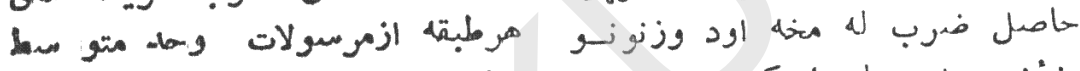

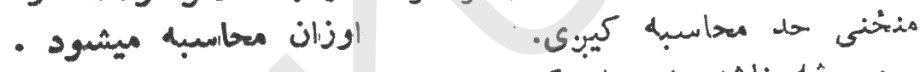

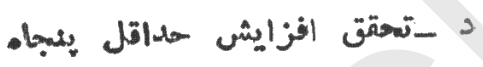

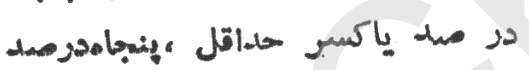

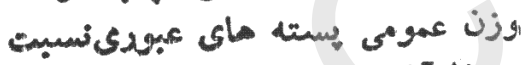

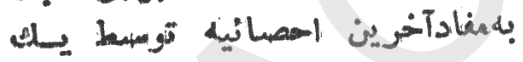

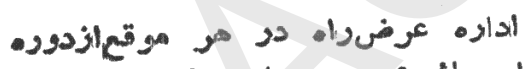

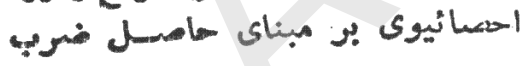

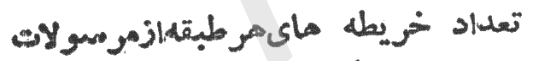

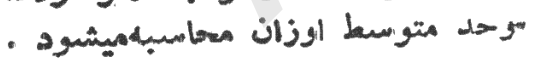

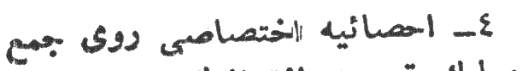

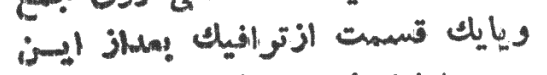

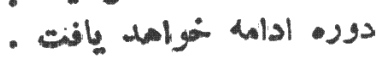

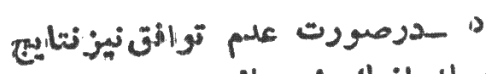

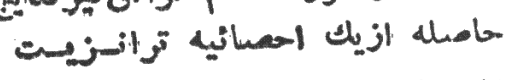

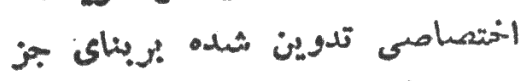

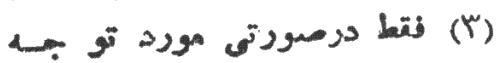

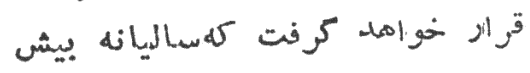

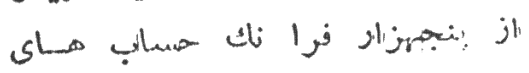
د

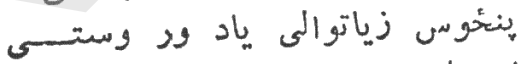

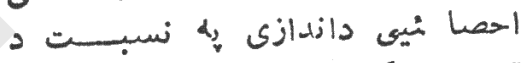

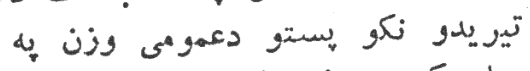

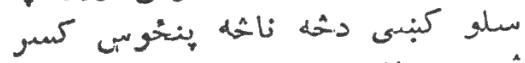

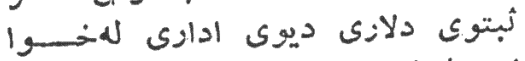

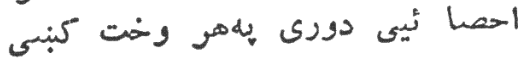

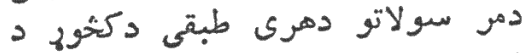

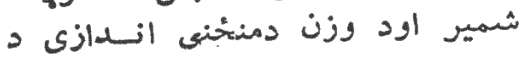
ضرب دماصل للهخخه محاسبه كيب.ى.

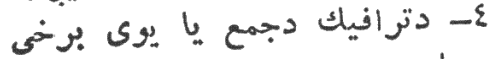

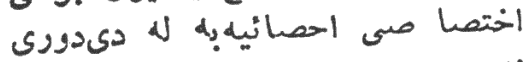

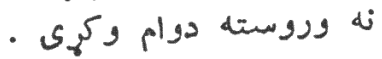

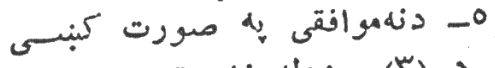

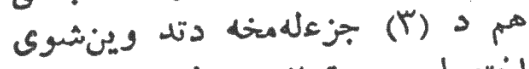

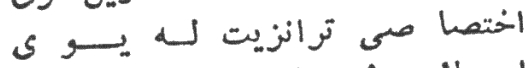

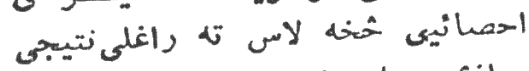

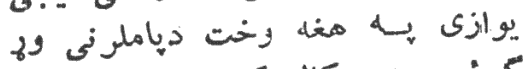

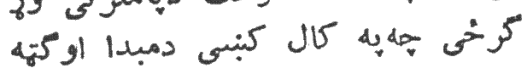




\section{? ?}

نشريه رمهمى دولت جهمورى الفانسمتان

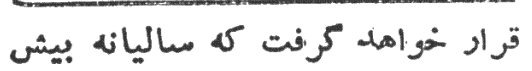

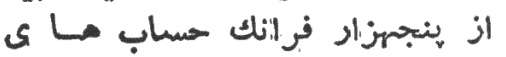

بينادازه مبداء وادارث ذينفع رانشان

. بلدهد

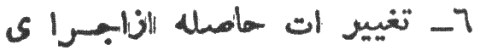

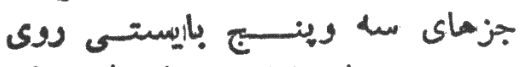

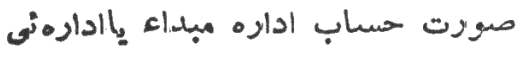
كعنبلا عمل توانزيت رالانجام داده

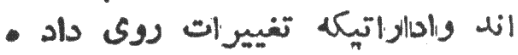

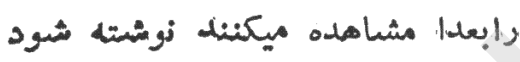

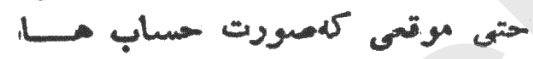
براى بعضى ادارات دوحلسا|قل تصيين

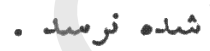

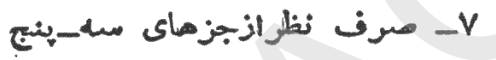

وشش دوصسدت انحر.افكسامسلو

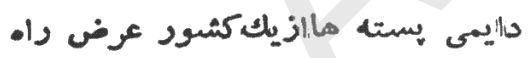
توسط يك كشودديكر طالبثم.اننيتى ماته

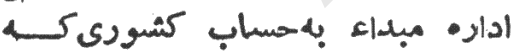

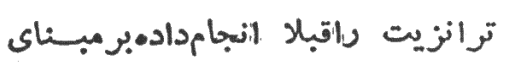

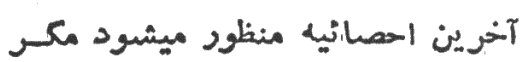

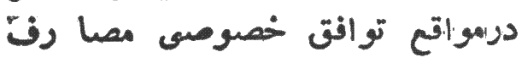

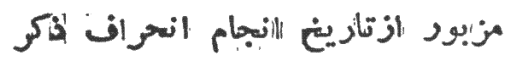

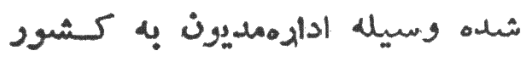

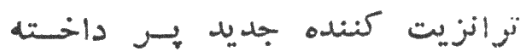
(باقيدارد ) (rr) Irots

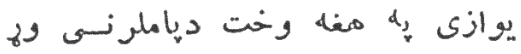

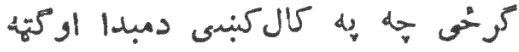

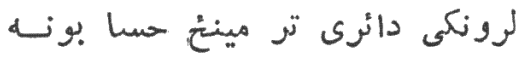

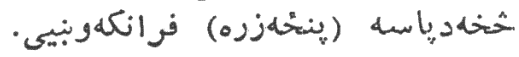

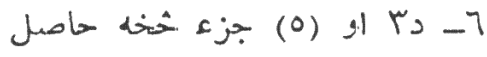
شوى بدلون دمبداء يا هغو داو دائرويه

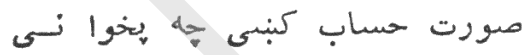
دترأنزيت عمل صر ته ته رسولى اود

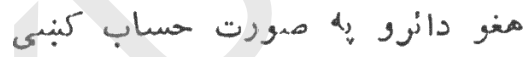

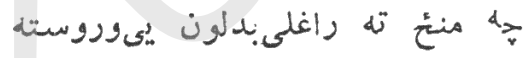
ليدنى وى ليكل كيب.ى اوحتى بهنه

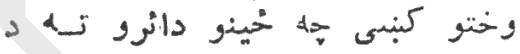

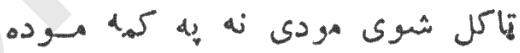

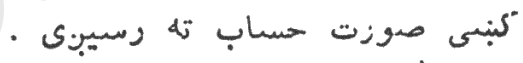

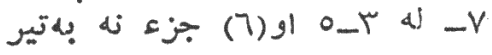

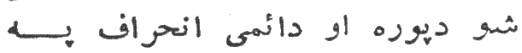

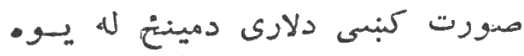

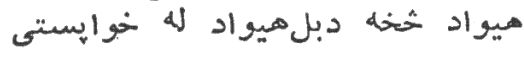
دمبداء دائرى ترانزيتى طلب دهيواد دئه

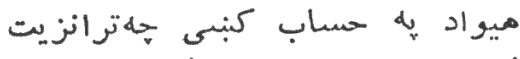

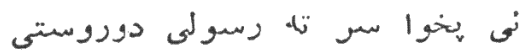

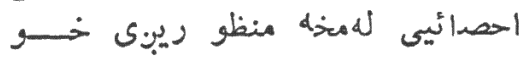

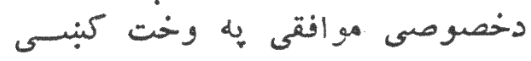

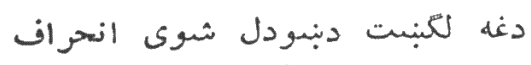

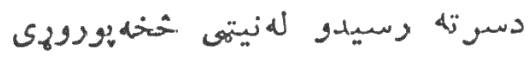

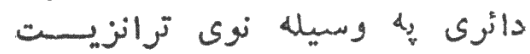

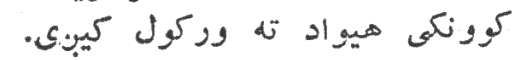
باتى لرى 


\section{थै्चए}

\section{اعلاناتو ثبتعالايم تحارتى}

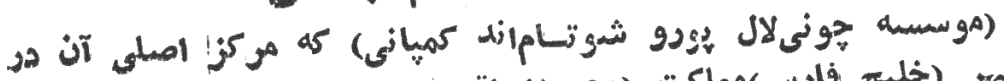

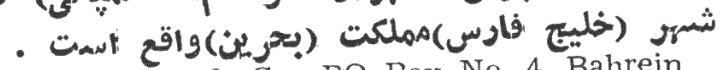
CHUNILAL PURU SHOTTAM \& Co., PO Box No. 4. Bahrein Persian Gulf.

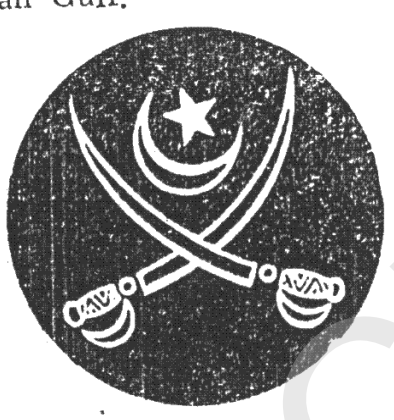

مينخو:ا هد علامت منسوبريه خودرا

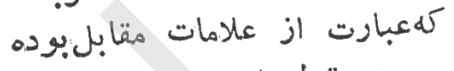

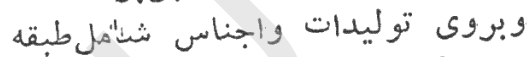

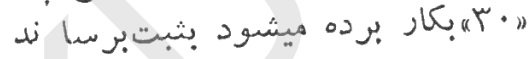

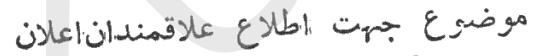

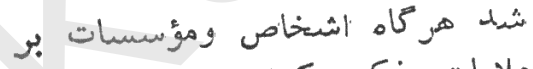

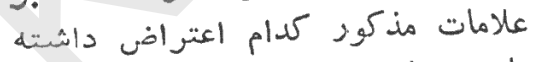

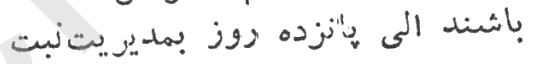
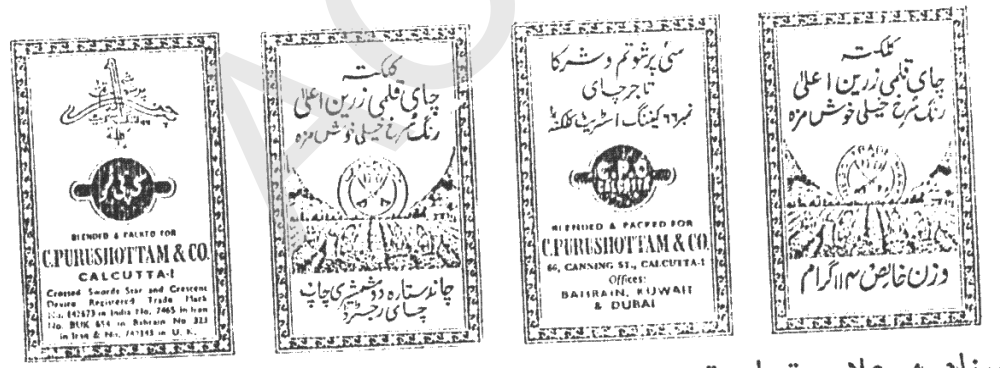

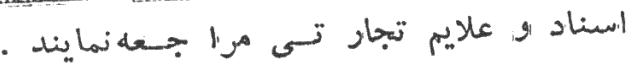

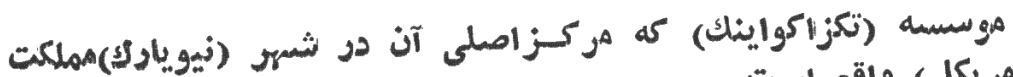

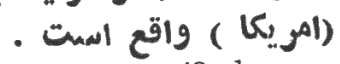

TEXACO Tnc., a Delaware Corporation, 135 East 42nd Street, New York, N.Y. 10017, U.S.A.

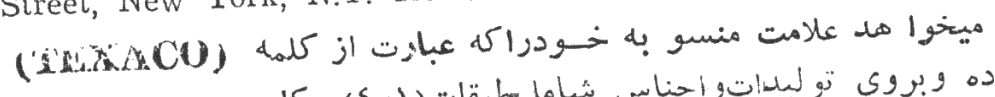

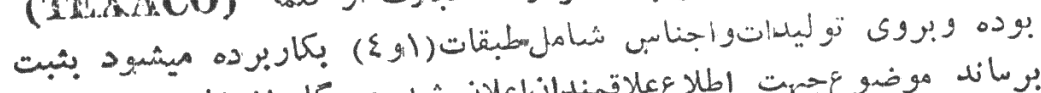

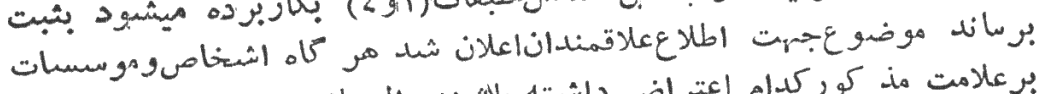

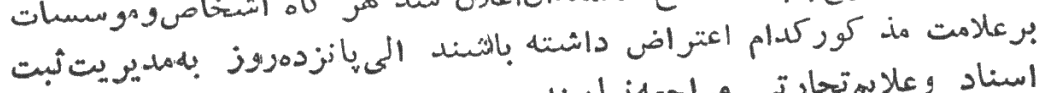

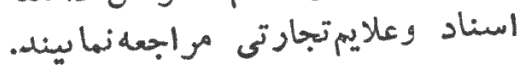




\section{Fo.0.}

شماره (rr) سمال

يه هرو ينخلسهو ودمحو خِيريبى

موسسه (دى كوكن كولا كميا نى) كه مر كز اصلمى آن در شسور (اتلانتا)

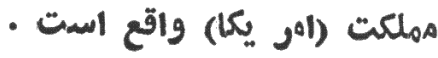
THE COCA COLA COMPANY, a Delaware Corporation 310 North Avenue, N.W Atlanta N-W Atlanta, Georgia, 30313 U.S.A. ميخوا هد علا مت منسو به خودرا

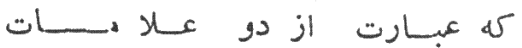

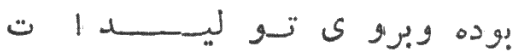
MIR. PIBB

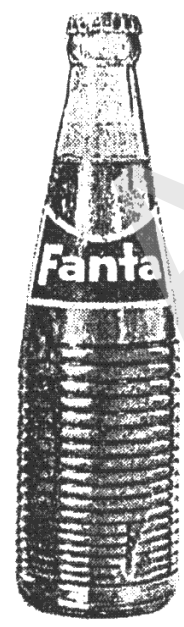

وإجناس شاملطبقه (Yr) بكاربوده

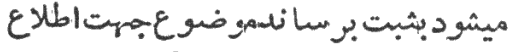

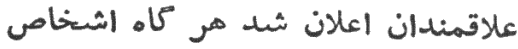

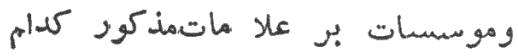

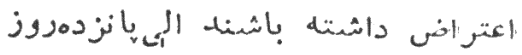
بمديريت ثبت السناد وعلايم تجارتى دانى

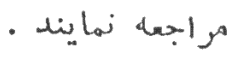

مو مسسه (سمو سيتا فارما سيت)كه

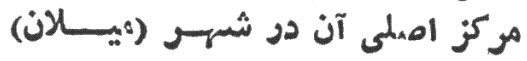

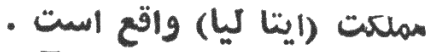
Societa Far Maceutici Italia, Lar Go Guido 1-2 Milan, Italy.

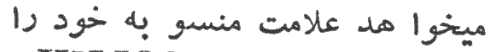

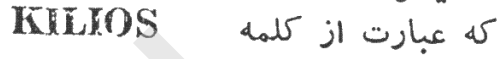

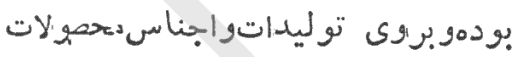

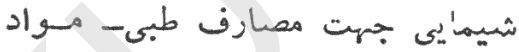

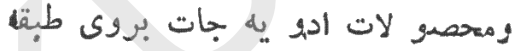

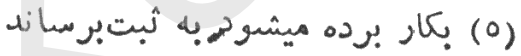

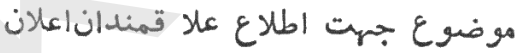

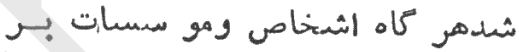

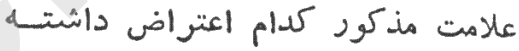

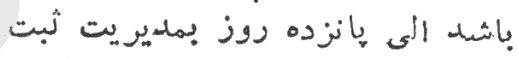

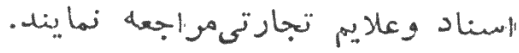

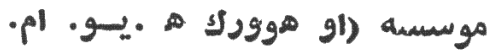

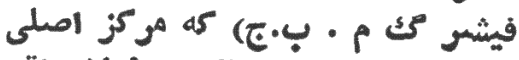

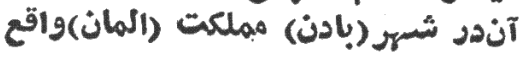
است

UHU-Werk H.U.M. Fisher Gmbh. Post Fach 1440, 7580 Buhi (Baden) Germany.

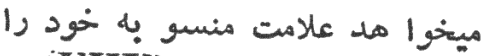
(UHU) كه عبارت از كله عله

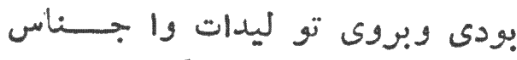

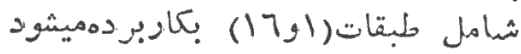

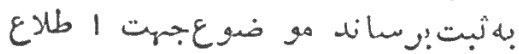

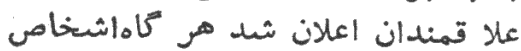

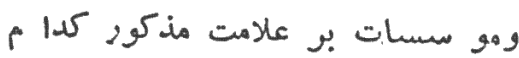

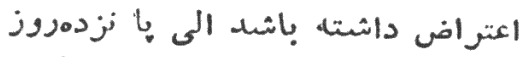

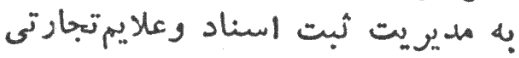
مرا جعه نمايند ملت لهيت 


\section{siso?}

نشريه وسهى دولت بهمهودى إفنانسيتان

\section{FLUDEX}

ميباشد وبروى وتوليداتواجنامبشامل

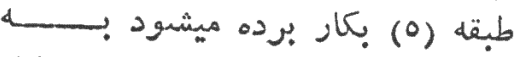

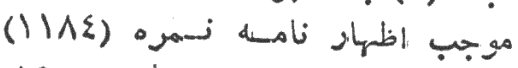
(19)(تاريخى

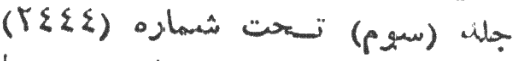

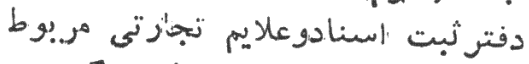

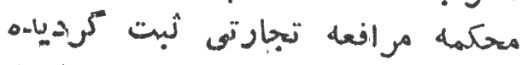

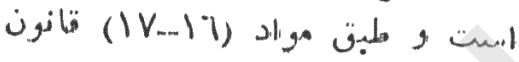

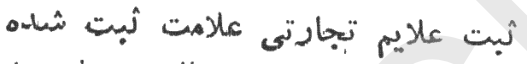

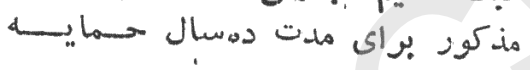

\section{كز لثنافت ؤورشد} ميكرد مد مد

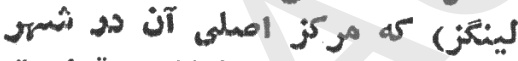

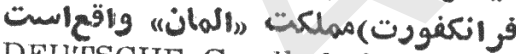
DEUTSCHE Gesellschaft fur Schadlingsbe Kampfung $\mathrm{mbh}$, Neue Mainzer Str. 1 Frankfurt M. Germany.

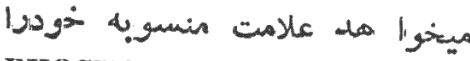

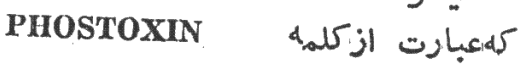
بو.ده وبروى توليدات واجنأس شامل

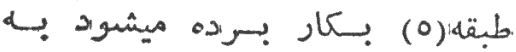

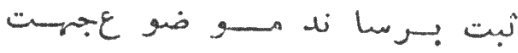

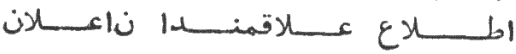

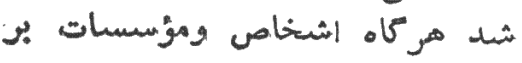

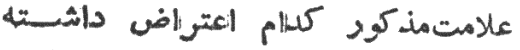

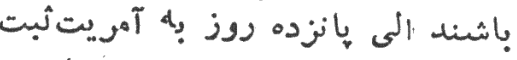
اسنادوعلايتم تجالر تى بمراجعه نمابله.
منه

مؤسسه (مكيز هركركاد هيروشن)

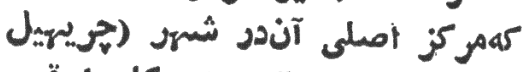

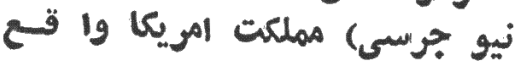
• است

MAGIC MARKWIR CORIORA'ITON! Magic Merker Lane, Cherrg Hill Industrial Park. Cherry Hill, New Jersey, U.S.A.

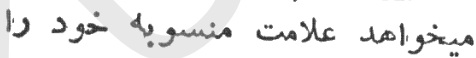

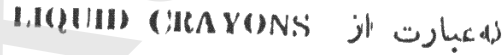

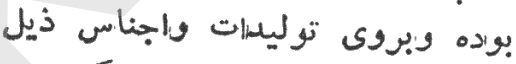

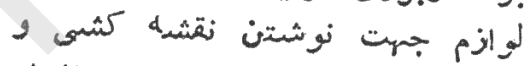

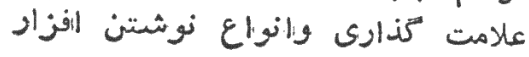

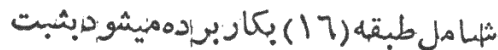

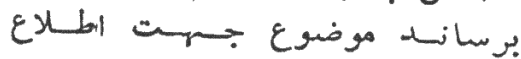

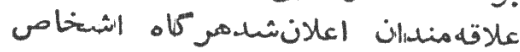

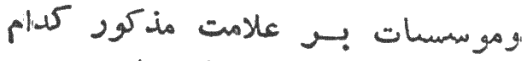

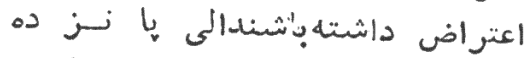

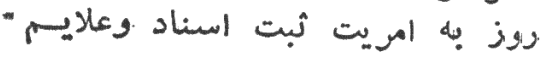

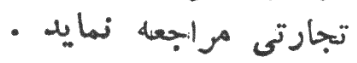

به تعقيب اعلان قبلى عالا مـت

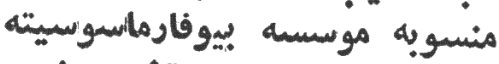
انونيم) كممركز اصلى آن در شمهر

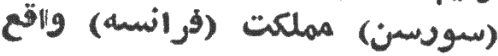
- المبت

BIOFARMA Societe Anonyme, 22. rue Garnier, Neuilly-SurSeine, Franc.

و علامت مذكور عبارت از كلمه 


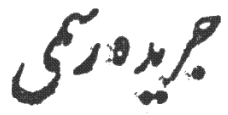

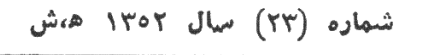

خصو صيات تجإ تى نُّاغلم

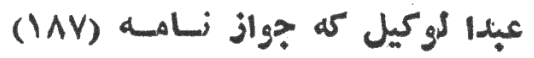

1)

قوار ذيل در دفتر ثبت اسناد وعلايم

تجار تى دياست ديوان تجارتمدكمه دئه استيناف عالى هركزى به ثبتردميده

: 1

اسماسم تاجر- عبدا لو كيل

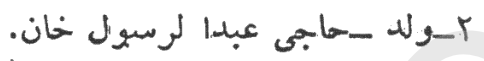

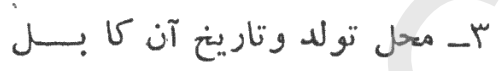

-

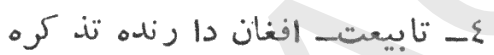

$.91 \cdot 47$

0- عنوان تجار ت - عبدالو كيل

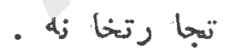

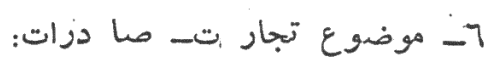

ميوه خشك وتازه ، قالين ، هوستونين

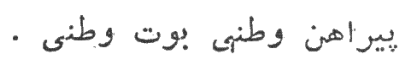

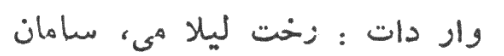

مو تو سلهان بر ق. بنجاره كمى. V_مو ضعتجارت_سواى فيض متحمد خان.

1- اشتخاصداراى مهلا حيتامضا-

امضاء عبدا لوكيل هدار اعتباراست.
دأفانستان د. جهمودى دولت وسهى خيرونه

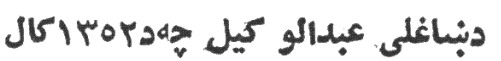

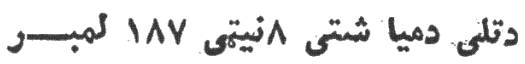

جواز نوى اخلى تجار تى خصوصيات

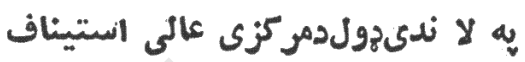

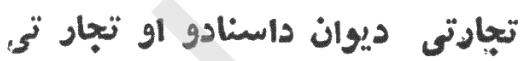
علامو، دثبت هيه دفتر كى ثبتشويدى.

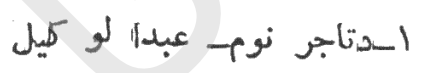

r- ديلار نوم-ح'جنى عبدالر سول.

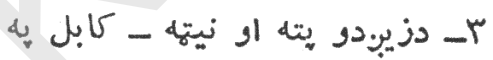
•

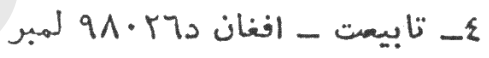

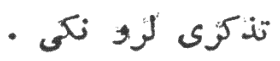

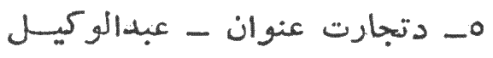
- تجائ تهنى 7- دتجارت مو ضوع -صا درات:

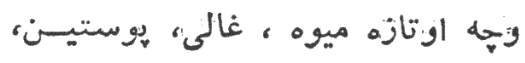
وطنى كميس او وطنى بوتة نها :

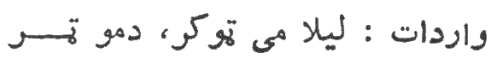
سامان ، دبر بنسنا سا مُن، بنجاركى ماردي

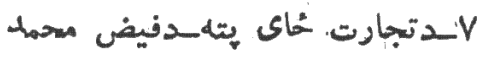

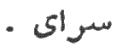

1ـ دلا سليـك ردا كمن كسان دعبدا لو كيل لا سليك اعتباز لرى. دلو كمان 


\section{约}

نشمريه رسهى دولت لجهمودى |لفانسمتان

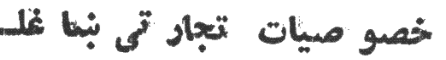

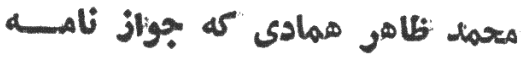
(1N0) مينمايد قراد ذيل در دفتر ثبتاسناد

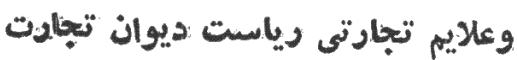

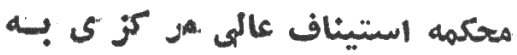
ثبت رسيده اسمت:

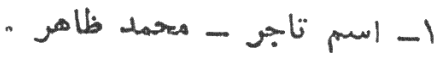

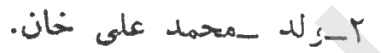

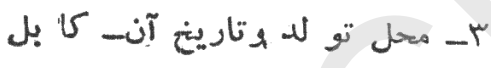
درسال

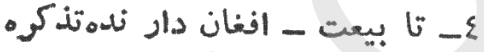
$1 \cdot 7004$

0ـ عنوان تجارت ـ ـ تجار تخانــ محمد ظ'هر همادى عنران تيارث

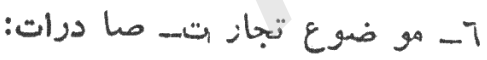
ميوه خشك و وتازه، قالين، يوست،

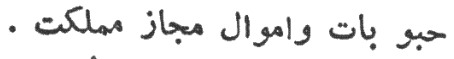

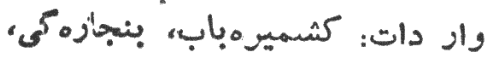

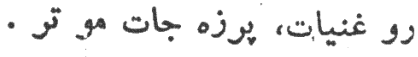
V- مو ضع تجارت جاده تيمسيسور 1ـ اشخا ص داراى صلا جيــت

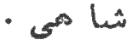

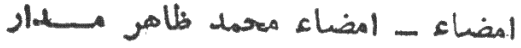

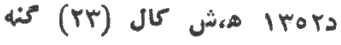

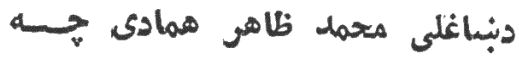

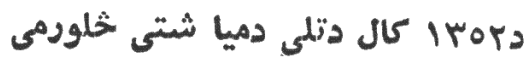

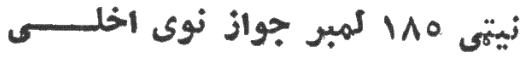

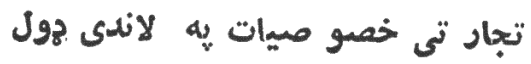

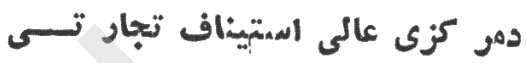

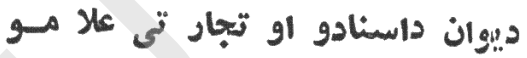

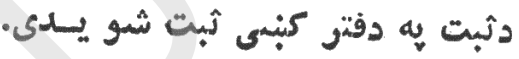

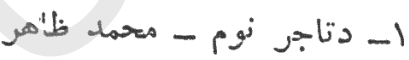

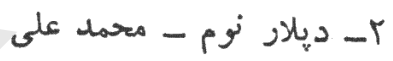

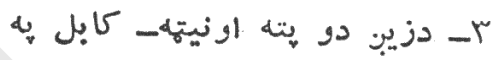
זrזrו كال كنبسى

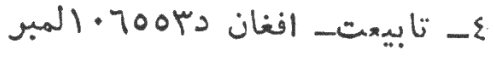
تذكرى لره نكى · تليق

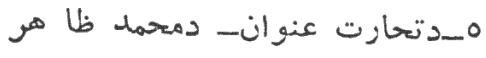
هم'دى تجار تحُى •

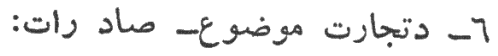
ويه اوتازه ميوه، غالى، يو ستكسى،

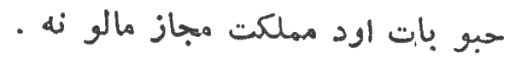

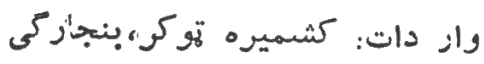
رو غنيات ، دمو تو ير زى •

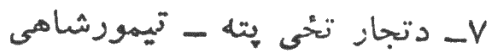

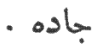
^ـ دلاسليك وا كمــن كساندمحمد ظاهر لاسليك داعتبار ون دى. 


\section{6.\%.}

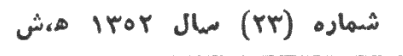

خصهو صبات تجارتى بشير لميتد

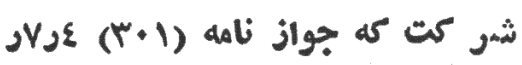
و ا

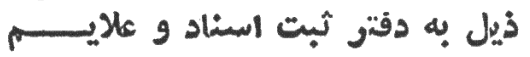
تبار تى وبامهت ديوان تجارتمحكمه استضيناف عالى هو كزى به ثبثردميله : 1- اسعم وعنوان شر كت- بشيسر - لمتيل

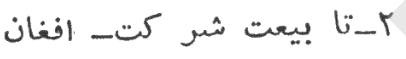

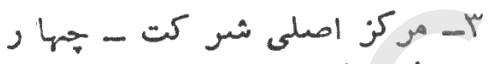
راهى طره باز خر خان

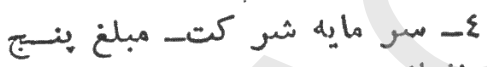
- U افنانى

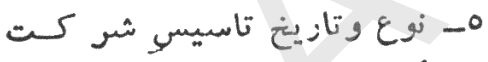
لمتيد ع ميزان 7ـ موضوع تجارت : مطادرات و

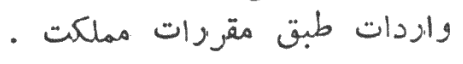

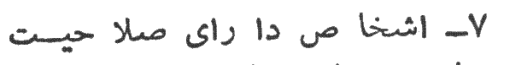

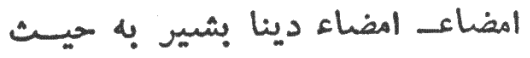

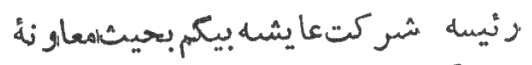

$$
\begin{aligned}
& \text { تشر كت اعتبار دارد . }
\end{aligned}
$$

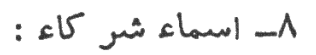

ا-مدينا بشر بنت هجمد اسمعيل
دافنانستان 2 جهمودى دولت دسمى خهرونه

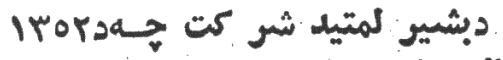
كال وتلى دميا شتق خلور هى نيتهـى

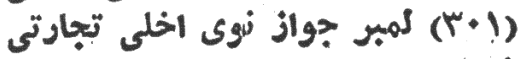

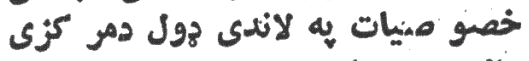

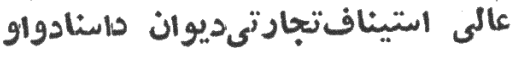

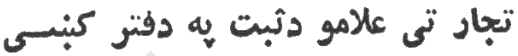

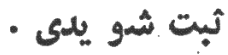
ا- دشو كت نوم او عنوان-شيشير r-بدشر كت تابيعت _انغا ن.

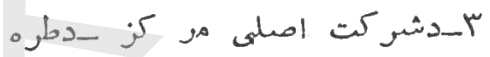
باز غان خلور لاند

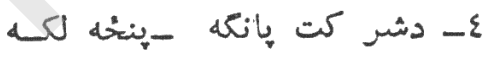
- افغانى

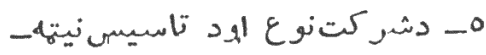
لمتيد ي 7- دتجازت مو ضوع- صادرات: او وار دات دمملكت لله مقر واتو مبره

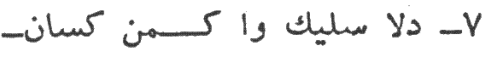
ددينا بشير دشر كت دريسيسيتيث اوعايشه بئم دشر كت معاو نهيح لانسليكو نه اعتبار لوى 1- دشر يكانو نو مو نله- الـدينا بشير دمحما اسمعيل لور.

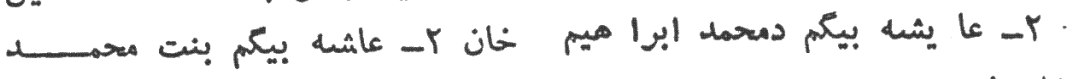
.
- لون 


\section{0\%?}

اعلانات ولبت عايم تبادىى

خصو صيات تباوتى بنها غلله

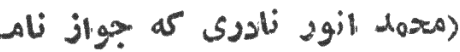

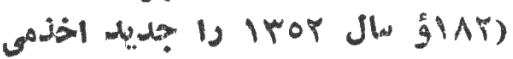

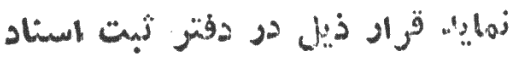

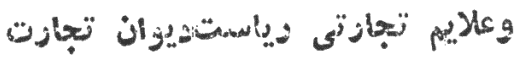

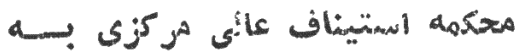

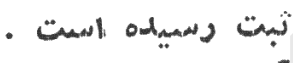

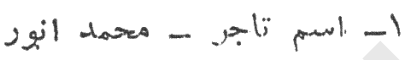
r-

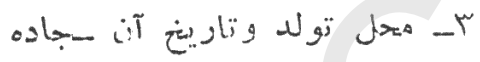

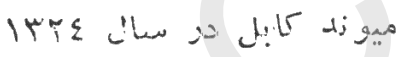

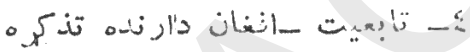
00 YVir

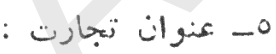
.

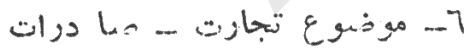

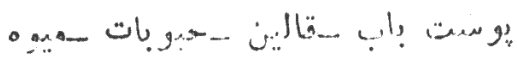
خششك وتازه

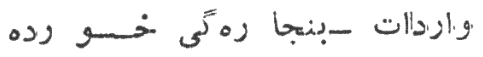

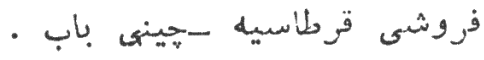
Vـ هو ضع تجارت ــ سراى سيد حبيب الل كابل مانج

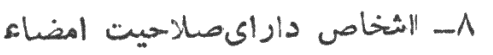
اعضاء عحمد انور نادوىمدار اعتبا. است

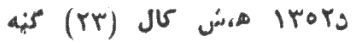

د بنماغلى متحمد انور نادرى جهد كارتي

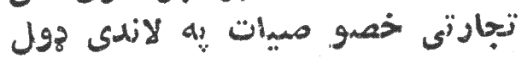

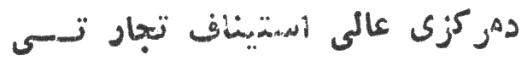
ديوان داسنادو او تجارتى كالامسو د ثبت يهددقتر كنبسي ثبت شويد

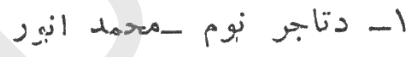

$$
\begin{aligned}
& \text { T- T: }
\end{aligned}
$$

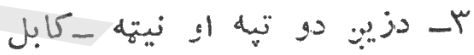
• له

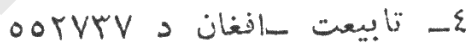

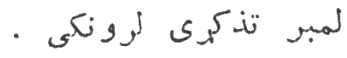

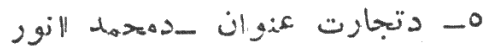

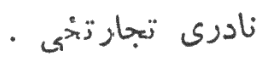

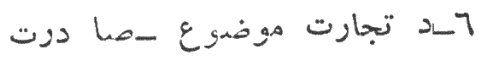

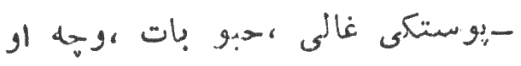
تازه ميوه .

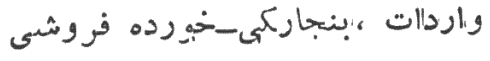
- قرطاسيه - بحينى

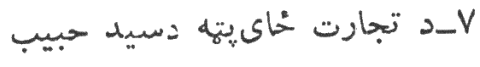
الله سراى المارت 1- دلانسليك والكمن كسيـان- دايك

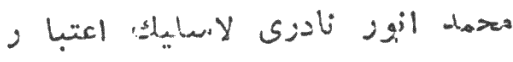

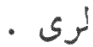




\section{0.}

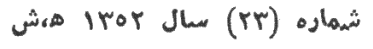

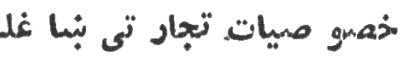

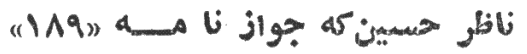

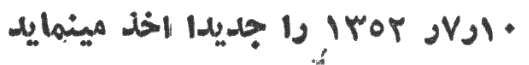

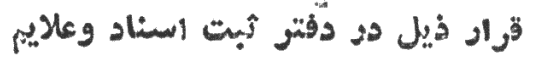

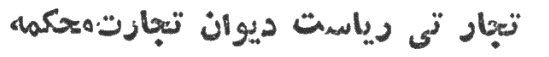
المتيناف عالى هركزى به ثبت ديترسيده

$$
\text { : المnت }
$$

1- اسم تاجر - ناظر حسين

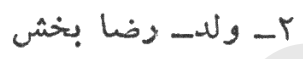

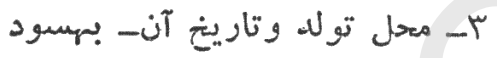

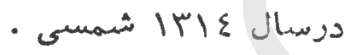

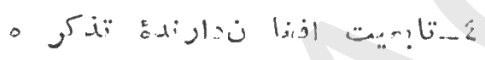
.VIITAT

0ـ عنوان تجازت ـ تجار تخانسه ناظر حسين

7- مو ضوع تجاربتصا درات_ميوه

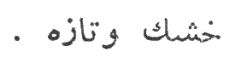

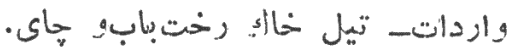

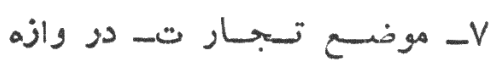
• لاهو دى

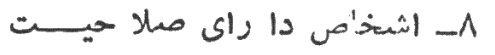

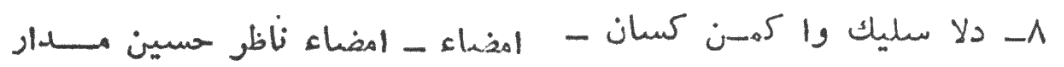
دناظر حسين لا سليك اعتبار لرى. اعتبار است .
دافغانستان د جمهورى دولت وسمى خهرونه

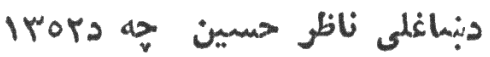
كال دتلى دميا شتى لسمى نيتى

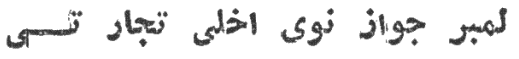

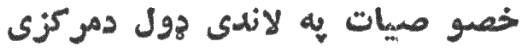
عالى استيناف تجبارتى ديوانئداسنادو

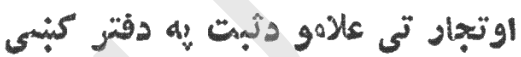
ثبت شو يدى : 1- دتاجر نوم - ناظر حسين r-بديلا: نو م-زضا بخش.

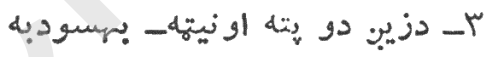

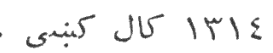

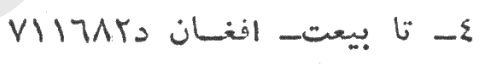
لمببر تذكرى لرونكى لماني ○ـ دتجارت عنوان ـ دنا ظرحسين تجار تئى

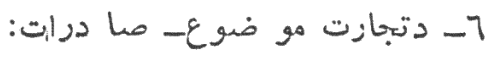
وبها او تازه ميك ه.

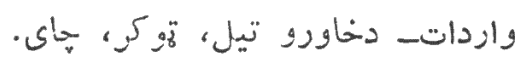

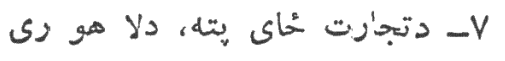
دروازه . 


$$
6,0 \%
$$

درهر بانزده دوز يكمراتبه نشر هيشمو.

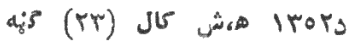

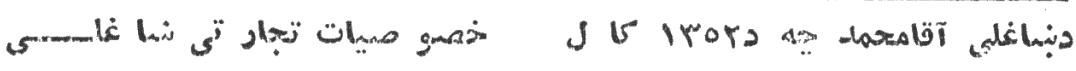

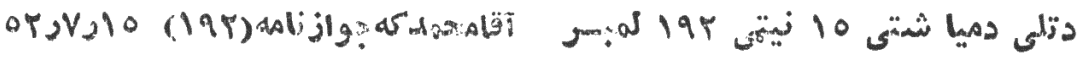

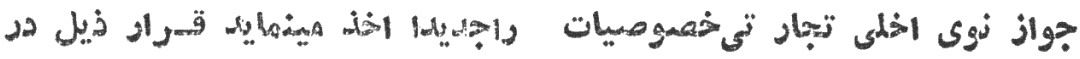

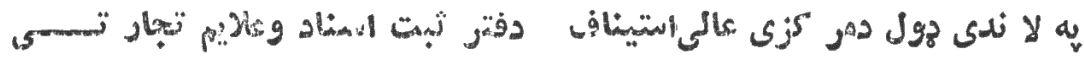

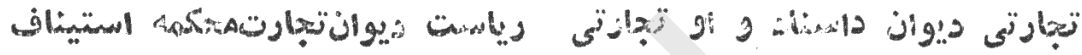

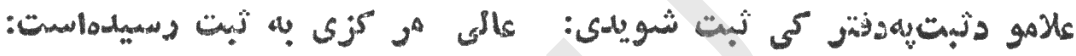

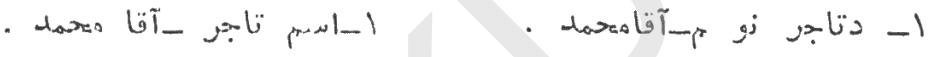

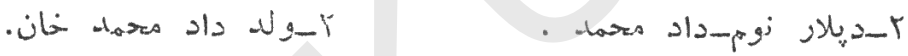

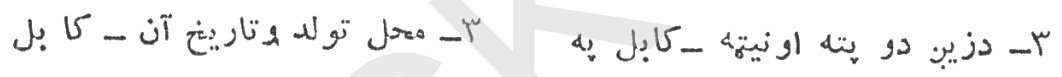

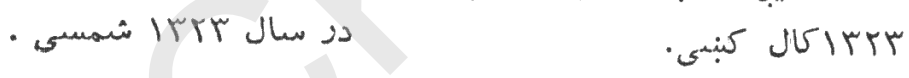

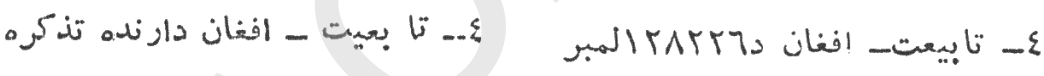

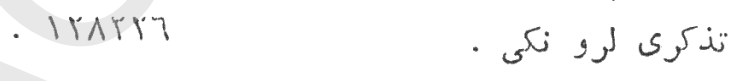

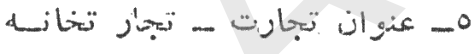

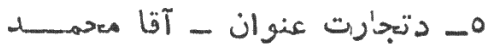

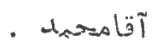

نجار تصنى ن

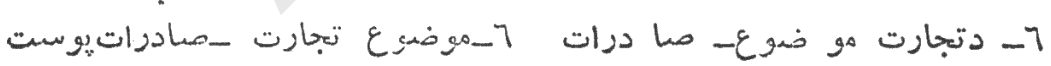

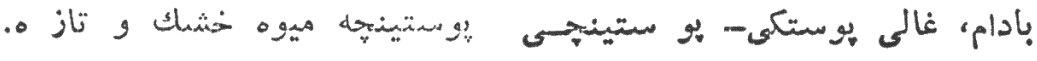

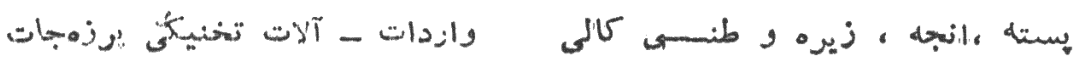

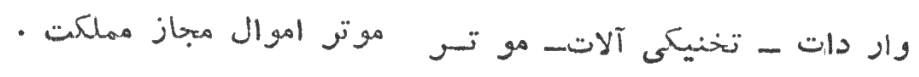

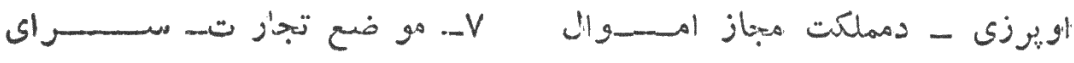

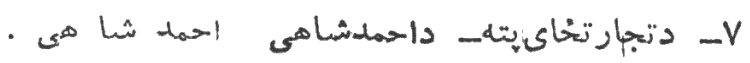

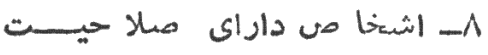

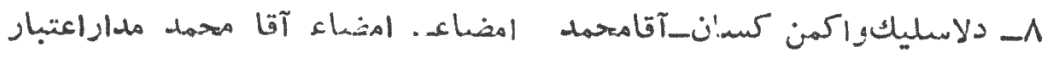

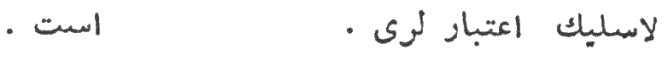




\section{थص్}

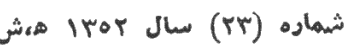

خمو صيات تجار تى نباغل

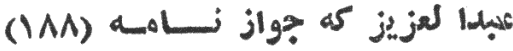
درل

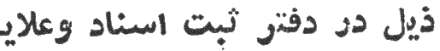

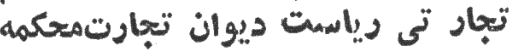

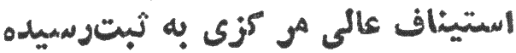

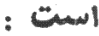

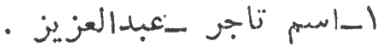
r

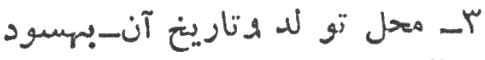

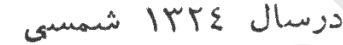

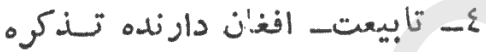
- $V \cdot 10 \wedge \varepsilon$

0- عنوان تبازت ـ تجار تنا خه عبدا لجزيز

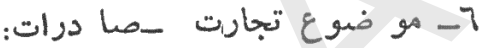

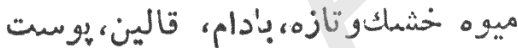

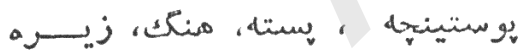
البسه وطنى البهن

يه هرو ينخلسو ورخدو خيريبيى

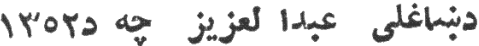

كا لدتلى دهياثثتى اتمى نيتي

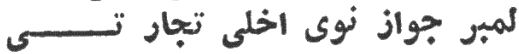

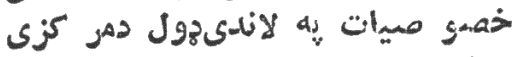

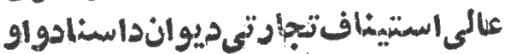

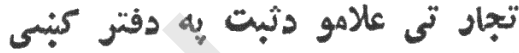
زبت شو يدى على 1- داجير نوم- عبدا لعزيز

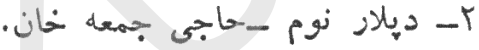

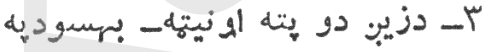

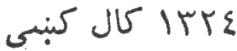

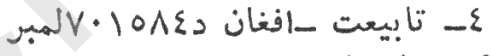
• تذكرى لرون ناليعى

0ـ دتجارت عنوان - دعبدا لعزيز

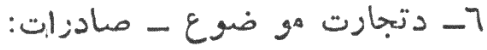

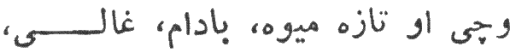

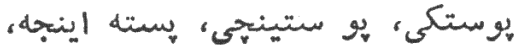

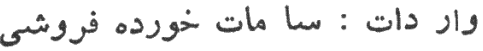

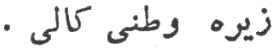

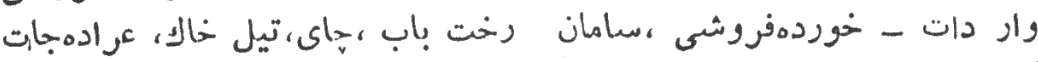

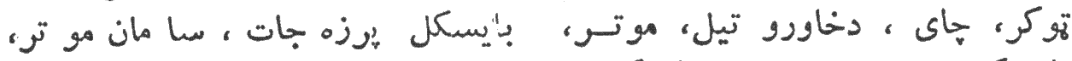

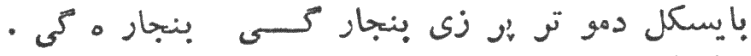

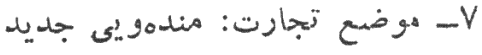

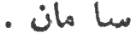

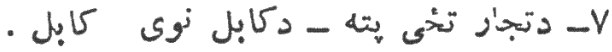

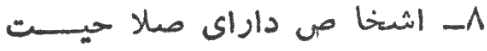

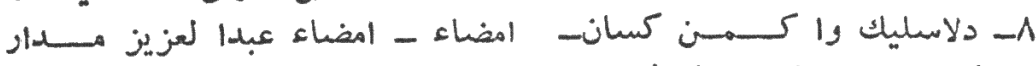
دعبدا لعزيز لا سليك اعتبار لرى. اعتبار است . 


\section{Q}

درهر يانزده روز يكمرتبه تشر ميشمود

خصو صميات تستجار تسى نباغلى

قاسم على كسله جواز نساهل (191)

قرا

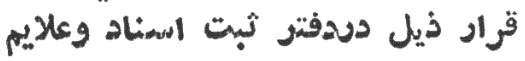
تجارتى دياست ديوان

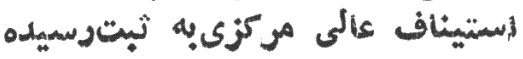
السمت :

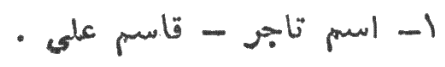

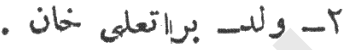

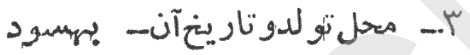

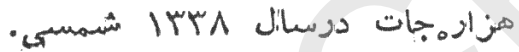

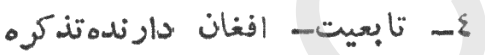

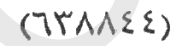

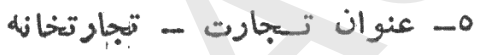

$$
\text { ق قاسم ع' عنى }
$$

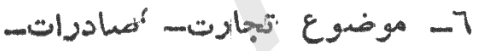

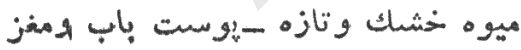

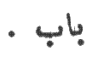

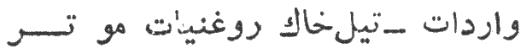

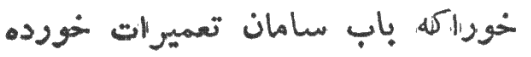

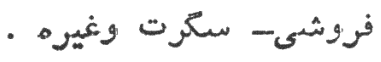

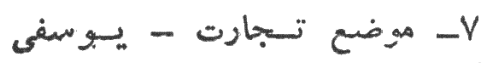

$$
\text { ماركيت }
$$

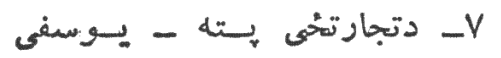

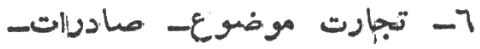

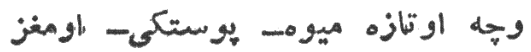

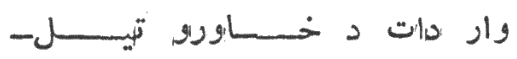

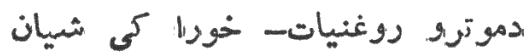

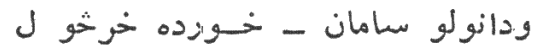
سكرت اونو سونون

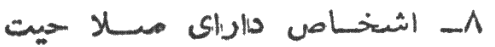
مار كيت

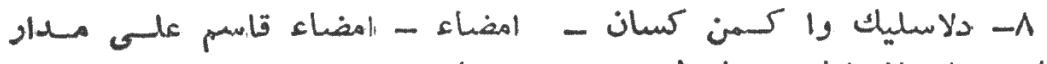

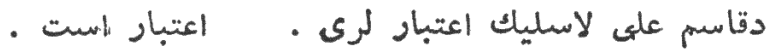




\section{S Son?}

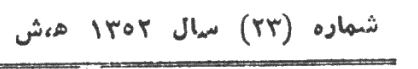

خصوصيات تجارتى نباغلى حاجى

دافغا نستان جمهورى دولت دسمى خيرونه

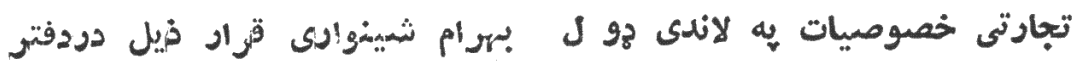

دمركزى استيناف تجارتى ديسوا ن تبت اسناد وعلايم تجارتى ريا ست

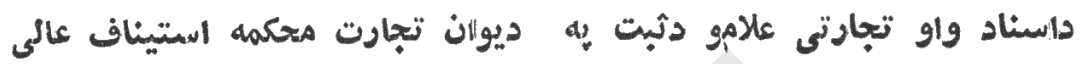

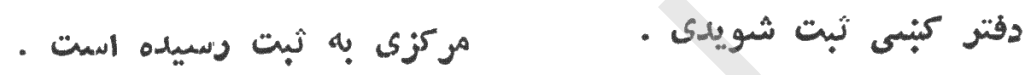

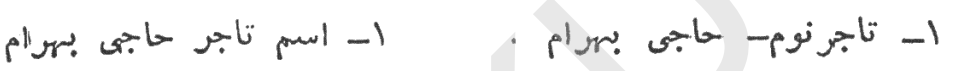

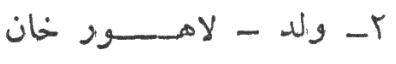

r rيلار نوم - لاهور خان.

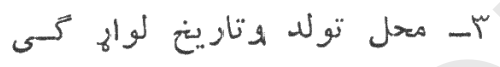

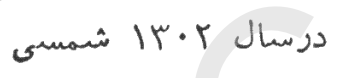

ع- تابعيت هينستو نستان

0- عنو.ان تجارت - تبارتخانه

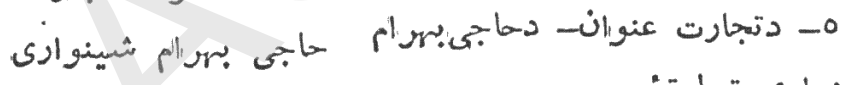

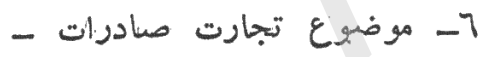

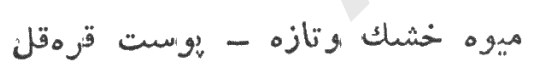

-

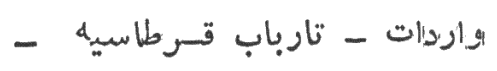

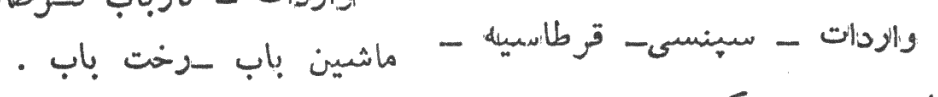

- V موضع تجارت -باغ عليمردان

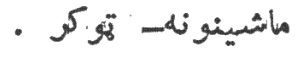

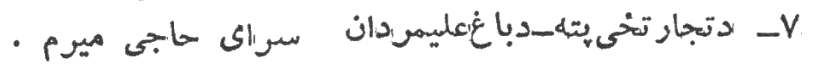

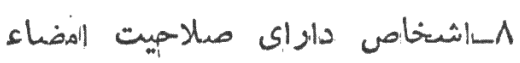

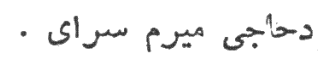

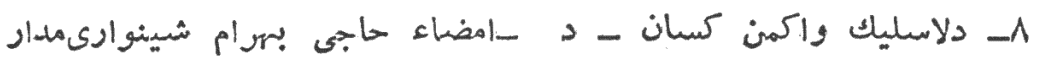

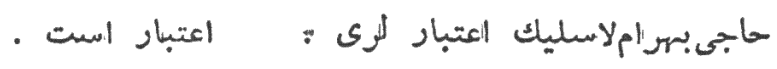




\section{? P P P}

نشريه رسمى دولت جمهودى الفانستان

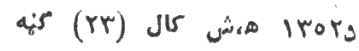

خهمو صيات تجار تقى بناغلى ،

د نّاغلى دام مهـن تسجار تسى

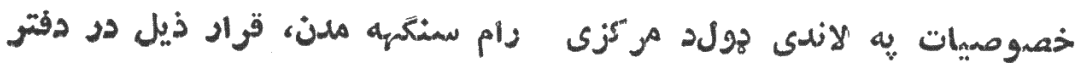
عالىاستينافتجارتى ديوانداسبنادو، ثبت اسناد و علايم تجارتى وياست

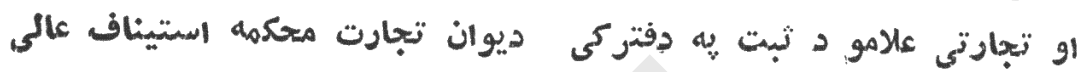

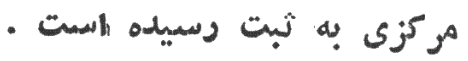

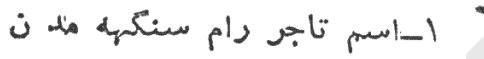

• ثبت شمويدى

- r- وله - ايشر مسنRه

1- دتابمه نوم رام سنك لمك

- r- ديلار نوم ايشر

r.... محل تولد وتاريخ آن ولايت

• هوיوان سال

r-بدزيب.دو يته او نيتهيه - بيونوان

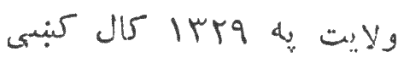

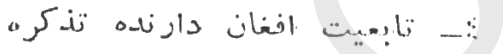

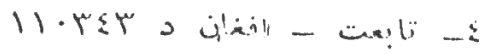

نمبr.

0- عنوان تجارت ، تجار تخانس

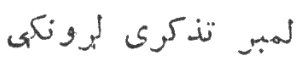

رام سنكه ملن.

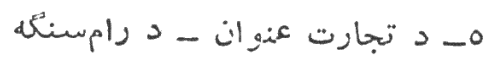

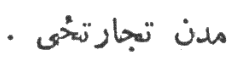

7- موضموع تجارت 1 ،صادرات

7- د تجانرت موضبوع صادرا|ت

ميوه خششك و تازه ، بو ستين باب

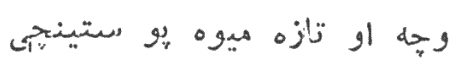

r-واردات ، رختباب سيمسارى

و'اردات- تهوكى سيمسارى بنجارثى دهى

· بنجاره

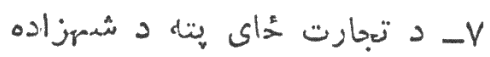

V_موضع تجارت ،سراى شهزاده

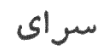

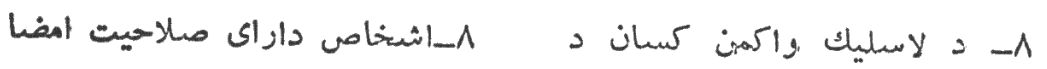

رام سنكة مدن لاسليك أعتباولمى إمضاى رام سنكهلمداراعتباد است. 


\section{$5,0 \%$}

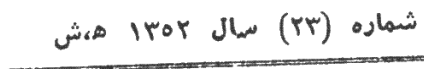

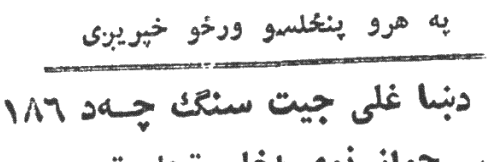

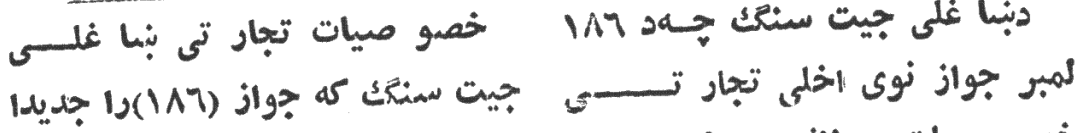

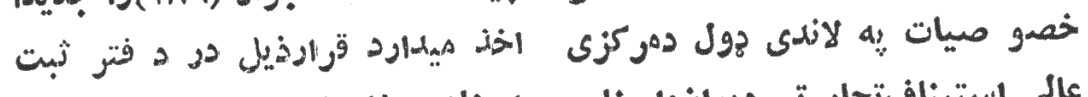

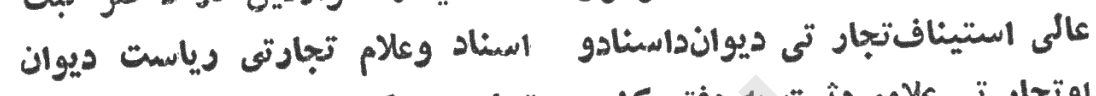

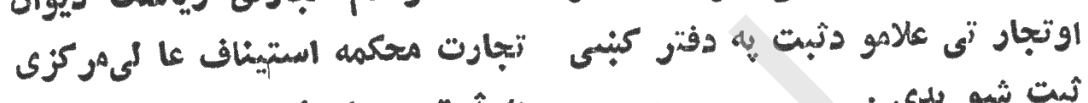

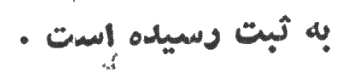

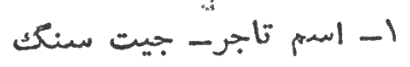

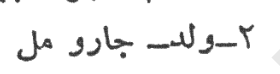

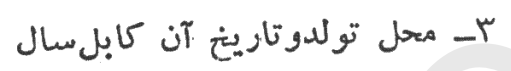

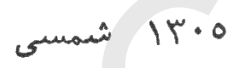

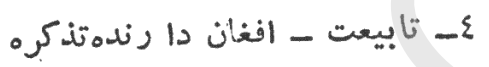

$$
\text { .1. ₹าข }
$$

$$
\text { جيت م- عنوان تجارت - متجار تخانسه }
$$

7ـ هو ضوع تجارت ـ صا درات:

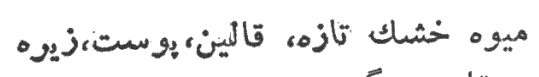

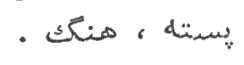

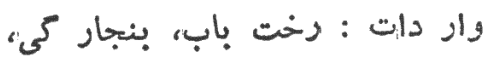

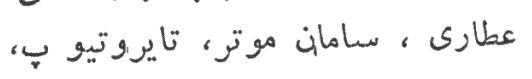

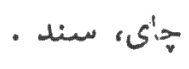

لامسوضع تجار تـ افند افضل ماركيت

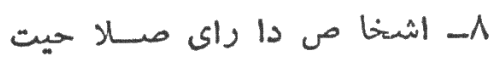

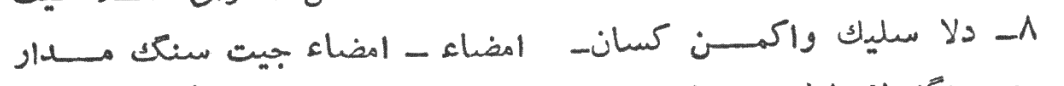

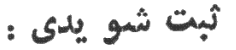
1- دتاجر نوم - جيت سنك

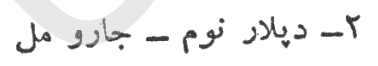

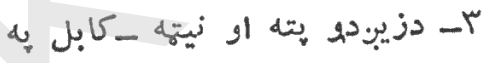

$$
\text { ع.r. }
$$

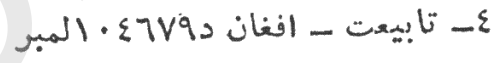

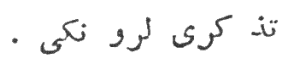

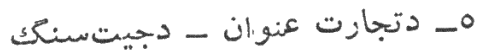

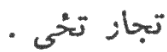

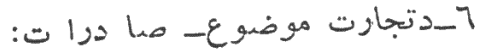

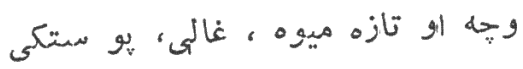

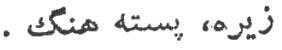

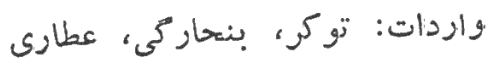

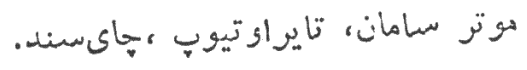

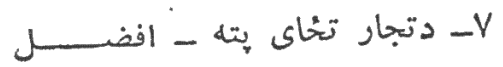
مار كيت . دجيت سنكك لاسليك داعتباروي دى. 


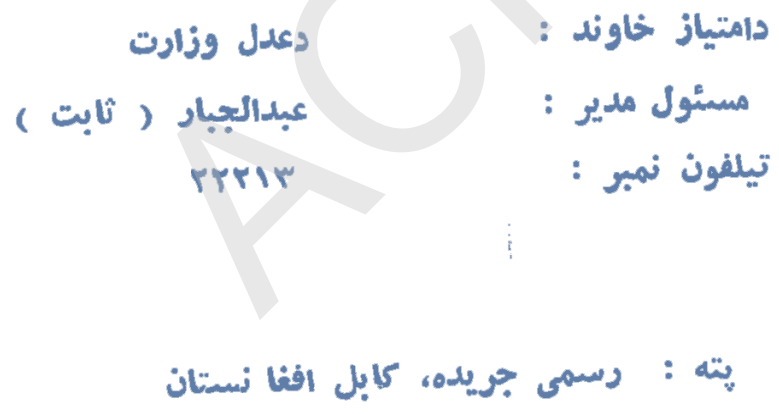




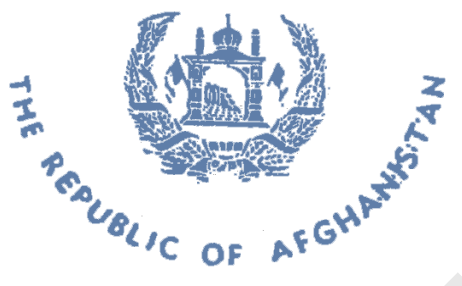

OFFICIAL GAZETTE

\author{
Issue No. 255 \\ Date November: 6, 1973 \\ Rddress: Ministry of Justice \\ Kabul, Afghanistian
}

Director: Abdul Jabar Sabit

دولتى مطبعه

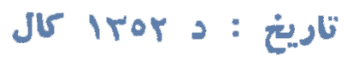

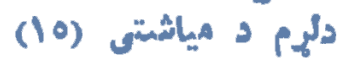

